J. Product. \& Dev., 23(3): $717-737(2018)$

\title{
EFFECT OF DIETARY OF PALM POLLEN AND GINSENG SUPPLEMENTATION ON PRODUCTIVE, REPRODUCTIVE TRAITS AND SOME PHSIOLOGICAL PAMETERS OF LAYING JAPANESE QUAILS.
}

\author{
Wesam A. Ibrahim*; Bealish A.M.A.*; Tawfeek M. I. ** and Rashwan A.A.** \\ * Animal Production Research Institute., Agriculture Research Centre, \\ Ministry of Agriculture, Dokki, Giza, Egypt. \\ ** Animal \& Poultry Production Department, Faculty of Technology \& \\ Development, Zagazig University, Zagazig, Egypt \\ e.mail:mostawms@hotmail.com,mostaw100@yahoo.com
}

\section{ABSTRACT:}

A total number of 108 Japanese quail birds (72 females and 36 males) at 6 weeks old was used to evaluate the supplementation of either Palm Pollen(PP) or Panax Ginseng (PG) or their mixture to the diets of laying quail on productive, reproductive traits and some physiological parameters. Quails were weighed individually, randomly $(201.97 \mathrm{gm} \pm 1.13$ body weight $)$ distributed into four experimental groups. Each group contained 27 birds (18 hens and 9 males). The first group was fed the basal diet as control group (without any supplementation), the second group was fed the basal diet and supplemented with $5 \mathrm{~g} P P / \mathrm{kg}$ diet, the third group was supplemented with $0.5 \mathrm{~g} P G / \mathrm{kg}$ diet and the fourth group was supplemented with $5 \mathrm{~g} P P+0.5 \mathrm{~g} P G / \mathrm{kg}$ diet during the experimental period from 7 to 22 weeks of age. Each group was divided into three replicates of 6 females and 3 males in each.

The results indicated that quails fed either Palm Pollen or Panax Ginseng or their mixed had significant $(P<0.01)$ increased live body weight change (weight gain), egg production percentage and egg mass as well as improved $(P<0.01)$ feed conversion ratio $(g \mathrm{feed} / \mathrm{g}$ egg mass) as compared with control group. However, percentage of fertility and hatchability of egg sets had significant $(P<0.01)$ increased. Sperm motility $(\%)$ and sperm-cell concentration $\left(\times 10^{9} / \mathrm{ml}\right)$ of quails treated with supplemented of $P P$ and $P G$ significantly $(P<0.01)$ increased compared with the other treatment groups, while dead spermatozoa (\%), sperm abnormalities (\%) and acrosomal damage (\%) of quails treated with PP or PG and their 
mixture significantly $(P<0.01)$ decreased compared with the control group. Fertility, and hatchability of egg sets laying were significantly $(P<0.01)$ increased compared with control group. Total protein increased significantly $(P<0.01)$ However, blood serum tri-glycerides, cholesterol and glucose concentration decreased significantly $(P<0.01)$. The histological findings in testes of male treated with either PP or PG or their mixture showed an improvement of the cellular activity and spermatogenesis in the testicular sections.

Conclusively, supplementing of Palm Pollen $5 \mathrm{~g} P P / \mathrm{kg}$ diet or Panax Ginseng $(0.5 \mathrm{~g} P G / \mathrm{kg}$ diet $)$ and their mixture to the diet of laying quails can be used safely significantly increasing appease productive and reproductive performance of quails.

Key words: Laying Quail, Palm Pollen, Ginseng Panax Productive, Reproductive Fertility, Hatchability, Testicular.

\section{INTRODUCTION:}

It is supposed that herbs can be used as alternative to natural antibiotic growth promoting as feed additive. The long duration use of antibacterial products as growth promoter at sub beneficial dosage resulted in antibiotic impervious microbial strains in poultry; Hence is measured aggressive for human and ban has imposed over the use of these products as growth promoter (Aarestrup et al 2001 and Jang, 2011) and in significances there have been reports signifying in increased disease out breaks (Casewel et al 2003).

Herbs are long used to treat human, animals and a mammoth quantity of the masses still depends and uses these natural remedies (Pan et al.,2014). These natural compounds carry out different types of activities. Such as antibacterial, antifungal, antioxidant, immune modulators, enzyme secretions stimuli, antispasmodic and gut environment modifiers (Bhatt, 2015).

The treatment of different levels of palm pollen of laying hens had a significant $(\mathrm{P}>0.05)$ hen day production, the cumulative eggs, eggs weight , eggs mass and feed conversation (Shanoon et al., 2015). In addition palm pollen supplementation improve semen quality (volume, concentration and livability) and hatchability percentage (Abou El- Naga, 2014).

Panax ginseng root extract is added diets of laying quails to both levels (5 or $10 \mathrm{mg} / \mathrm{kg}$ ) has increased egg production and egg weight compared to the control group (Özcan, 2016). Yan et al., (2011) showed that the birds fed wildginseng adventitious root meal at level 1 or $2 \%$ supplemented diets had increased egg production percentage when compared to control group. Hen- 
day egg production was greater for red ginseng by-product (RGB) supplemented with 5.0 or $10.0 \mathrm{~g} / \mathrm{kg}$ diet of RGB treatment groups than that for basal treatment group (Kang et al., 2016). Azazi et al., (2011) observed that the fertility $(\%)$ and hatchability $(\%)$ were significantly increased by dietary ginseng supplementation (150 and $300 \mathrm{mg}$ ginseng/Kg diet) as compared with those of the control group. Furthermore, previous studies suggested that dietary ginseng impaired avian hepatic cholesterogenesis, reduced serum total cholesterol and LDL cholesterol levels in avian species (Qureshi et al.,1983 and Muwalla and Abuirmeileh, 1990) and Jang et al., (2007). Hassan and Abdel-Wahhab(2006) and Kumar et al (2003) reported that Ginseng causes to significant decrease in total chromosomal aberrations, sperm abnormalities and increase in testosterone concentration and sperm numbers and motility.

Therefore, the present study was conducted to investigate the effect of using palm pollen and Panax Ginseng powder as medicinal plants and their mixture on productive and reproductive performances of Japanese quails.

\section{MATERIALS AND METHODS}

\section{Birds, management and experimental design:}

The present study was carried out at Inshas Poultry Research Station, Animal Production Research Institute, Agricultural Research Center, Egypt, from October 2016 to February 2017.

A total number of 72 laying hens and 36 males of Japanese Quails, 6 weeks old, were chosen from a large commercial flock. All selected birds were randomly distributed into four experimental treatment groups (18 females and 9 males / each treatment group). The first group was fed the basal diet as control group, the second group was fed the basal diet and supplemented with $5 \mathrm{~g} \mathrm{PP} / \mathrm{kg}$ diet, the third group was supplemented with $0.5 \mathrm{~g}$ PG/ $/ \mathrm{kg}$ diet and the fourth group was supplemented with $5 \mathrm{~g}$ PP $+0.5 \mathrm{~g}$ PG $/ \mathrm{kg}$ diet, during the experimental period from 7 to 22 weeks of age. Each group was divided into three replicates of (six females and three males).All birds were legs banded and housed in cages and maintaining similar managerial and conditions environment with a photoperiod length of $17 \mathrm{~h}$ daily, $33^{\mathrm{c}}$ air temperature and relative humidity $(58 \%)$. The basal experimental diets were formulated according to NRC (1994). Experimental diets were formulated to be isonitrogenous and isocaloric to cover the nutrients requirements (Table 1) 
Table (1): Ingredients and chemical analysis of the basal diet of laying Japanese quails.

\begin{tabular}{|c|c|}
\hline Ingredients & $(\%)$ \\
\hline Yellow corn & 58.45 \\
\hline Soybean meal $(44 \% \mathrm{CP})$ & 25.80 \\
\hline Corn gluten meal $(62 \% \mathrm{CP})$ & 6.70 \\
\hline Vegetable oil & 1.30 \\
\hline Dicalcium phosphate & 1.10 \\
\hline Limestone & 5.70 \\
\hline Common salt $(\mathrm{NaCl})$ & 0.34 \\
\hline Premix* & 0.30 \\
\hline DL-Methionine & 0.05 \\
\hline L-Lysine & 0.06 \\
\hline Choline chloride & 0.20 \\
\hline Total & $\mathbf{1 0 0 . 0 0}$ \\
\hline \multicolumn{2}{|c|}{ Determined chemical analysis (\%) } \\
\hline $\mathrm{CP} \%$ & 19.85 \\
\hline $\mathrm{CF} \%$ & 3.30 \\
\hline $\mathrm{EE} \%$ & 2.70 \\
\hline \multicolumn{2}{|l|}{ Calculated chemical analysis** } \\
\hline $\mathrm{CP} \%$ & 20.01 \\
\hline $\mathrm{CF} \%$ & 3.36 \\
\hline $\mathrm{EE} \%$ & 2.76 \\
\hline $\mathrm{ME}(\mathrm{kcal} / \mathrm{kg})$ & 2890 \\
\hline $\mathrm{Ca} \%$ & 2.50 \\
\hline Avilable Phosphorus \% & 0.35 \\
\hline L-Lysine \% & 1.00 \\
\hline DL-Methionine \% & 0.45 \\
\hline Methionine + Cyst \% & 0.80 \\
\hline
\end{tabular}

*Premix added to the $1 \mathrm{~kg}$ of diet including Vit.A 10000 I.U; Vit D3 2000 I.U; Vit. E $15 \mathrm{mg}$; vit. K3 $1 \mathrm{mg}$; vit B1 1mg; vit. B2 5mg; vit. B12 $10 \mu \mathrm{g}$; vit B6 1.5mg; Niacin 30mg;

Pantothenic acid 10mg; folic acid 1mg; Biotin $50 \mu \mathrm{g}$; choline $300 \mathrm{mg}$; zinc 50mg; copper 4mg; iodine $0.3 \mathrm{mg}$; iron $30 \mathrm{mg}$; selenium $0.1 \mathrm{mg}$; manganese $60 \mathrm{mg}$ and cobalt $0.1 \mathrm{mg}$.

**According to Feed Composition Tables for Animal \& Poultry Feedstuffs Used in Egypt (2001) and NRC (1994).

recommended by Agriculture Ministry Decree (1996). Feed and water were provided ad libitum throughout the experimental periods. All Japanese quails were kept under the same managerial, environmental and hygienic conditions. 


\section{Measurements:}

Daily egg number and egg weight $(\mathrm{g})$ were recorded for each quail and feed intake $(\mathrm{g})$ was recorded weekly. Egg production and body weight change were calculated for monthly intervals during the laying period (7to 22 weeks) as egg number/hen/period for each replicate and calculated the average of the whole experimental period. Egg mass (g/d) was calculated by multiplying egg number by average egg weight during laying period. Feed conversion was calculated as divided ( $\mathrm{g}$ feed/g egg mass).

\section{Semen quality:}

Semen tests were exclusively gathered twice at the end of test period by the massage method from all males. Immediately after semen collection, semen, ejaculate volume were measured using graduate collecting tubes. A drop of semen with the aid of a micro-pipette was placed on a pre-warmed microscope slide, then covered with a glass cover slip and examined at a magnification of $\times 400$. Several fields were examined and an estimate to the nearest $10 \%$ of the motile sperm was made. Motility of semen samples was expressed as the percentage of motile spermatozoa having moderate to rapid progressive movement and cells that are motile under their own power (Ommati et al., 2013). At least 10 microscopic fields were examined for each semen sample. Eosin-Nigrosine stain was used to determine the percent of morphologically sperm abnormalities and dead spermatozoa. For sperm cell concentration $(\mathrm{x} 10 \% \mathrm{ml})$ a droplet of diluted semen (1:200 in distilled water) semen was tenderly put on both councils of a Neubauer hemocytometer and the number of spermatozoa was determined microscopically (Ommati et al., 2013). Acrosome damage of spermatozoa was determined according to Waston (1975).

\section{Fertility and hatchability (\%):}

At 10, 14, 18 and 22 weeks of experimental periods, 30 eggs from each treatment were collected and incubated. After hatching, the chicks were checked and non-hatched eggs were broken to decide the rates of fertility and hatchability. Fertility was calculated as the rate of fertile eggs from the total number of set eggs, while the hatchability was calculated as the hatched chicks from the total fertile eggs. All information about hatchability rate was subjected to arcsine square, attached the change rate before the examination. The relative humidity and temperature in the incubator was $55 \%$ and $37.5{ }^{\circ} \mathrm{C}$ during the period from 1-15 day. On the $15^{\text {th }}$ day of incubation, the eggs were 
moved separately into hatching nests and then placed in the hatchery for the remainder of the incubation period at $65 \%$ relative humidity and $37.2^{\circ} \mathrm{C}$. Unhatched eggs were broken and examined microscopically to determine the age of the late embryo at (15 to $18 \mathrm{~d}$ plus pipped) mortality.

\section{Blood parameters:}

At the end of experimental period, six ( 3 females and 3 males) quails were randomly chosen of each treatment group, slaughtered, blood samples ( 3 females) were collected into in heparinized test tubes. Each sample from each individual was divided into two samples. The first sample (fresh blood) was used to evaluate the total count of red and white blood cells as well as the differential counts of leucocytes (lymphocyte and heterophil). The other sample was centrifuged at $3000 \mathrm{rpm}$ for 20 minutes. The separated plasma was stored in a deep freezer at $-20^{\circ} \mathrm{C}$ until assayed for total protein (TP) $(\mathrm{g} / \mathrm{dl})$, albumin ( $\mathrm{Al})(\mathrm{g} / \mathrm{dl})$, total cholesterol (Tch) $(\mathrm{mg} / \mathrm{dl})$, Triglycerides (TG) $(\mathrm{mg} / \mathrm{dl})$, glucose $(\mathrm{mg} / \mathrm{dl})$ and estrogen according to the manufacture recommendations of commercial kits.

\section{Histopathological examination:}

Testes was the end of experimental period, testis were removed from each slaughtered bird ( tree males) and immersion - fixed in 10\% formalin solution at room temperature. Autopsy samples ( $4 \mu$ tissue sections) were fixed in $10 \%$ formalin saline for twelve hours. Serial dilutions of alcohol (methyl, ethyl and absolute ethyl) were used. Specimens were cleared in xylene embedded in paraffin at $56^{\circ} \mathrm{C}$ in hot air oven for $24 \mathrm{~h}$. Paraffin bees wax tissue blocks were prepared for sectioning at 4 micron thickness by sledge microtome. The obtained tissue sections were collected on glass slides, deparaffinized and stained by Haematoxylin and Eosin ( $\mathrm{H}$ and $\mathrm{E}$ ) and subsequently processed for histopathological examination under light microscope (Banchroft et al., 1996).

\section{Economical efficiency (EEF):}

Economical efficiency of egg production was calculated from the inputoutput analysis which was calculated according to the price of the experimental diets and eggs produced. These values were calculated as the net revenue per unit of total cost.

\section{Statistical analysis:}

The experiment was conducted as a Completely Randomized Design with four treatment groups in a one way arrangement were analyzed according to 
Snedecor and Chocoran (1982) using ANOVA procedures of SAS (SAS, 2004). The following model was used to study the effect of test materials on parameters investigated as follows:

$$
\mathrm{Yij}=\mu+\mathrm{Tj}+\mathrm{eij} \text {. }
$$

Where: Yijk $=$ Observation for each dependent variable, $\mu=$ Overall mean, $\mathrm{Ti}$ $=$ Treatment effects $(i=1,2 \ldots$ and 4$)$, eij $=$ Random error.

Significant difference among means of treatment groups was detected by Duncan's multiple range test procedures (Duncan, 1955). The differences were considered significant at $(\mathrm{P} \leq 0.05)$.

\section{RESULTS AND DISCUSSION:}

\section{Productive performance of laying quails}

Productive performance for laying Japanese quails of different experimental groups are presented in Table 2. Results obtained revealed that dietary of mixture of PP + PG had improved significantly $(\mathrm{P}<0.01)$ live body weight change, while, egg production percentage was increased $(\mathrm{P}<0.01)$ significantly in laying quails treated with $\mathrm{PG}$ and mixture of PP + PG as compared with control group. But treated with PP or PG or their mixture had improved significantly $(\mathrm{P}<0.05 \& \mathrm{P}<0.01)$ egg mass, feed intake, as well as,

Table (2): Effects of Palm Pollen, Ginseng and their mixture between them on productive performance of the Japanese Quail layers from 7 to 22 weeks of age.

\begin{tabular}{lcccccc}
\hline Treatments & $\begin{array}{c}\text { Live } \\
\text { bodyweight } \\
\text { change (g) }\end{array}$ & $\begin{array}{c}\text { Egg } \\
\text { production } \\
(\boldsymbol{\%})\end{array}$ & $\begin{array}{c}\text { Egg } \\
\text { weight } \\
(\mathbf{g})\end{array}$ & $\begin{array}{c}\text { Egg } \\
\text { mass }(\mathbf{g})\end{array}$ & $\begin{array}{c}\text { Daily } \\
\text { feed } \\
\text { intake } \\
(\mathbf{g} / \mathbf{d})\end{array}$ & $\begin{array}{c}\text { Feed } \\
\text { conversion } \\
\text { (g feed/g egg } \\
\text { mass) }\end{array}$ \\
\hline Control & 32.73 & 62.14 & 11.70 & 814.24 & 27.87 & 3.84 \\
(Basal diet) & $\pm 1.37^{\mathrm{b}}$ & $\pm 1.41^{\mathrm{b}}$ & \pm 0.03 & $\pm 20.16^{\mathrm{c}}$ & $\pm 0.06^{\mathrm{b}}$ & $\pm 0.09^{\mathrm{a}}$ \\
Palm Pollen & 41.44 & 67.77 & 11.73 & 890.40 & 28.23 & 3.55 \\
(PP) & $\pm 2.01^{\mathrm{ab}}$ & $\pm 0.38^{\mathrm{ab}}$ & \pm 0.01 & $\pm 4.48^{\mathrm{b}}$ & $\pm 0.09^{\mathrm{a}}$ & $\pm 0.03^{\mathrm{b}}$ \\
Ginseng & 42.56 & 69.00 & 11.71 & 904.96 & 28.29 & 3.50 \\
(G) & $\pm 1.19^{\mathrm{ab}}$ & $\pm 0.14^{\mathrm{a}}$ & \pm 0.01 & $\pm 1.12^{\mathrm{ab}}$ & $\pm 0.03^{\mathrm{a}}$ & $\pm 0.01^{\mathrm{b}}$ \\
PP + G & 49.32 & 72.21 & 11.73 & 948.64 & 28.23 & 3.33 \\
\hline Sig. & $\pm 3.37^{\mathrm{a}}$ & $\pm 0.20^{\mathrm{a}}$ & \pm 0.01 & $\pm 3.36^{\mathrm{a}}$ & $\pm 0.01^{\mathrm{a}}$ & $\pm 0.01^{\mathrm{b}}$ \\
\hline
\end{tabular}

Means having different letters at the same column are significantly $(\mathrm{P} \leq 0.05)$ differed.

$*=\mathrm{P}<0.05 ; * *=\mathrm{P}<0.01 ; \mathrm{NS}=$ Not significant. 
improved feed conversion ratio as compared with control group from 7 to 22 weeks of age. However, egg weight was insignificantly increased by treatments as compared with control group.

These improves of egg production and egg mass may be caused to increase of FSH and LH hormones (Walzem et al., 1999) because PP have high concentration of estradiol and estrogen hormone (Arhaem, 2004). Moreover, PP diet have ability to increasing growth of ovary, ovary ducts and them functions and that caused in hen day production increasing. However, ginseng diet may improve physiological function and immunity, and exerts various pharmacological effects (Kiefer and Pantuso, 2003). Therefore, a beneficial influence of PG on performance hen was expected. Jang et al., (2007) and Kim et al., (2015) reported that fermented wild ginseng culture byproduct or red ginseng extracts could increase egg production, which may be attributed to the improvement in the health status of birds fed diets supplemented with ginseng.

\section{Reproductive performance of laying quails Fertility and hatchability:}

Data presented in Table 3 observed that the effect of dietary of either PP or PG, or their mixture diets on fertility and hatchability traits. Fertility and hatchability of egg sets of laying quails treated with their mixtures of PP or PG diet were increased significantly $(\mathrm{P}<0.01)$ when compared with control group. However, hatchability of fertile eggs treated with aforementioned diets improved insignificantly as compared with control group. It is known that Panax ginseng enhance male fertility by acting directly on the pituitary hormones as it reduces prolactin production or on the central nervous system, which increase dopaminergic actions. Therefore, the present study could be suggested that the nanoparticles of Panax ginseng increased the efficiency of the particles of this plant to arrive the target cells of the hypothalamus pituitary-testis axis to improve the fertility of male rats. Nanoparticles performed from plants known to contain high content of flavonoids. These nanoparticles provide a biologically new way to designing therapeutic agents and consequently a means of reducing the toxicity of metal nanoparticles.

\section{Some physiological Parameters \\ Semen Quality:}

Data presented in Table 4 showed the effect of dietary of either PP or PG or their mixture on semen quality. Sperm motility (\%) of laying quails treated 
Table (3):Effects of Palm Pollen, Ginseng and their mixture between then on Hatchability traits of the Japanese Quail layers from 7 to 22 weeks of age.

\begin{tabular}{ccccc}
\hline Treatments & $\begin{array}{c}\text { Fertility } \\
(\%)\end{array}$ & $\begin{array}{c}\text { Hatchability } \\
\text { of egg set } \\
(\%)\end{array}$ & $\begin{array}{c}\text { Hatchability of } \\
\text { fertile eggs(\%) }\end{array}$ & $\begin{array}{c}\text { Late } \\
\text { embryonic } \\
\text { mortality }\end{array}$ \\
\hline Control(Basal diet) & 79.03 & 61.11 & 77.41 & 10.56 \\
Palm Pollen(PP) & $\pm 0.61^{\mathrm{b}}$ & $\pm 1.23^{\mathrm{b}}$ & \pm 0.98 & \pm 1.47 \\
& 85.14 & 70.00 & 82.18 & 8.33 \\
Ginseng(G) & $\pm 1.23^{\mathrm{a}}$ & $\pm 1.68^{\mathrm{a}}$ & \pm 1.21 & \pm 1.44 \\
PP + G & 84.86 & 67.92 & 79.96 & 7.50 \\
& $\pm 0.84^{\mathrm{a}}$ & $\pm 1.82^{\mathrm{a}}$ & \pm 1.34 & \pm 1.73 \\
\multicolumn{1}{c}{ Sig. } & 87.22 & 72.08 & 82.69 & 6.39 \\
\hline & $\pm 1.87^{\mathrm{a}}$ & $\pm 1.05^{\mathrm{a}}$ & \pm 2.48 & \pm 2.27 \\
\hline
\end{tabular}

Means having different letters at the same column are significantly $(\mathrm{P} \leq 0.05)$ differed. $* *=\mathrm{P}<0.01 ; \quad \mathrm{NS}=$ Not significant.

Table 4): Effects of PalmPollen, Ginseng and their mixture between then on semen quality $(\mathrm{X} \pm \mathrm{SE})$ of the Japanese Quail layers from 7 to 22 weeks of age.

\begin{tabular}{lcccccc}
\hline Items & $\begin{array}{c}\text { Semen } \\
\text { ejaculate- } \\
\text { volume } \\
(\mathbf{m l})\end{array}$ & $\begin{array}{c}\text { Sperm } \\
\text { motility } \\
(\boldsymbol{\%})\end{array}$ & $\begin{array}{c}\text { Dead } \\
\text { Spermatozoa } \\
(\boldsymbol{\%})\end{array}$ & $\begin{array}{c}\text { Sperm } \\
\text { abnormalitie } \\
(\boldsymbol{\%})\end{array}$ & $\begin{array}{c}\text { Sperm-cell } \\
\text { concentration } \\
(\mathbf{X ~ 1 0} / \mathbf{m l})\end{array}$ & $\begin{array}{c}\text { Acrosomal } \\
\text { damage } \\
(\%)\end{array}$ \\
\hline Control & 0.42 & 75.00 & 16.20 & 19.17 & 3.74 & 6.50 \\
(Basal diet) & \pm 0.04 & $\pm 1.29^{\mathrm{c}}$ & $\pm 1.05^{\mathrm{a}}$ & $\pm 1.25^{\mathrm{a}}$ & \pm 0.21 & $\pm 0.43^{\mathrm{a}}$ \\
Palm Pollen & 0.48 & 80.00 & 12.80 & 16.50 & 4.03 & 5.00 \\
(PP) & \pm 0.07 & $\pm 1.29^{\mathrm{ab}}$ & $\pm 0.83^{\mathrm{ab}}$ & $\pm 1.28^{\mathrm{ab}}$ & \pm 0.24 & $\pm 0.73^{\mathrm{ab}}$ \\
Ginseng & 0.50 & 79.00 & 12.40 & 14.50 & 3.92 & 4.50 \\
$(\mathbf{G})$ & \pm 0.13 & $\pm 1.53^{\mathrm{b}}$ & $\pm 0.92^{\mathrm{b}}$ & $\pm 1.80^{\mathrm{bc}}$ & \pm 0.17 & $\pm 0.56^{\mathrm{bc}}$ \\
PP $+\mathbf{G}$ & 0.57 & 83.00 & 11.60 & 12.50 & 4.43 & 3.17 \\
\hline \multicolumn{1}{c}{ Sig. } & \pm 0.05 & $\pm 1.00^{\mathrm{a}}$ & $\pm 0.99^{\mathrm{b}}$ & $\pm 0.92^{\mathrm{bcd}}$ & \pm 0.13 & $\pm 0.48^{\mathrm{c}}$ \\
\hline
\end{tabular}

Means having different letters at the same column are significantly $(\mathrm{P} \leq 0.05)$ differed.

$* *=\mathrm{P}<0.01 ; \quad \mathrm{NS}=$ Not significant.

with combination of PP and PG was significantly $(\mathrm{P}<0.01)$ increased when compared with the control group, while dead spermatozoa (\%), sperm abnormalities (\%) and acrosomal damage (\%) of quails treated with mixture of $\mathrm{PP}$ and $\mathrm{PG}$ were significantly $(\mathrm{P}<0.01)$ decreased as compared with the control 
group. However, semen ejaculate volume and sperm cell concentration were insignificantly increased as compared with control group.

Malviya et al., (2011) indicated that the consumption of PP suspensions improved the sperm count, motility, morphology, and DNA quality with a concomitant increase in the weights of testis and epididymis. Constituents the palm pollen contains estradiol and flavonoid components that have positive effects on the sperm quality. Also, investigators showed statistically significant increase in serum testosterone levels in rats who received PP (Iftikhar et al., 2011; Bahmanpour et al., 2006). Palm pollen have been shown to increase in sperm concentration and motility with increased normal morphology and a significant increase in testosterone level in rats (Adaay and Mattar, 2012). PP caused a significant increase in sperm cell concentration (total count) and motility in male guinea pigs and adult male rats (Omar et al., 1989; Hassan et al., 2012). Zhiyue et al., (2002) indicated that the diet supplemented with $1.0 \%$ and $1.5 \%$ treatment significantly increased the sperm quantity, sperm activity compared with control group. Mousa et al., (2018) illustrated a significant improved in the cumulative egg production of the treated group. Egg weight, mass and feed conversion revealed a significant differences with date palm pollen $(0.5 \%)$ supplementation.

Sabah and Linjawi (2015) reported that Panax Ginseng treatment enhanced the fertility of male rats, which increased the secretion of serum free testosterone LH, and FSH and decreased the sperm abnormalities. Moreover, Panax Ginseng treatment inhibited the DNA damage and increased the expression levels of the fertility genes. These findings are in line with several studies, which found that supplementation of Panax Ginseng extract is effective to enhance the testicular function (Kim et al, 1999), and sperm viability, as well as, increase the quality of sperm in guinea pigs (Hwang et al, 2004).These results are agreement with those obtained by Tahani and Abdalhafid (2016) suggest that Panax ginseng root powder possesses profertility properties in male rabbits, which might be a product of both its potent antioxidant properties and androgenic activities.

Nocerino et al,. (2000) reported that aphrodisiac and adaptogenic properties of ginseng. The endothelial and neurogenic effects of ginsenosides in inducing relaxation of the corpus cavernosum may account for the aphrodisiac effect of Panax ginseng (Nocerino et al. 2000). Supplementation with either 150 or $300 \mathrm{mg}$ Ginseng / Kg feed improved semen quality and sperm cell concentration and decreased dead spermatozoa\% and abnormal 
spermatozoa (\%), compared with those of control group. This may be due to believed exert immune-stimulatory, anti-fatigue and hepato-protective physiological effects (WU and Zhong, 1999 and Azazi et al., (2011).

\section{Blood Parameters:}

Adding mixture of $5 \mathrm{~g} P \mathrm{P}+0.5 \mathrm{~g} \mathrm{PG}$ to the laying quail rations increased serum total protein significantly $(\mathrm{P}<0.01)$, while blood serum tri-glycerides was increased $(\mathrm{P}<0.01)$, significantly when treated with either $\mathrm{PP}$ or $\mathrm{PG}$, or their mixture diets as compared with control group, treated with $\mathrm{PP}+\mathrm{PG}$ mixture in the diets concentration decreased significantly $(\mathrm{P}<0.01)$ when compared to control groups. However, estrogen was insignificantly increased by treatment groups as shown in Table 5 .

The present study is compatible with findings of Kim et al., (2003; Kim and Park, (2003); Kawak et al., (2010) and Shin et al., (2011), who mentioned that ginseng has a hypolipidiemic potential. This may be due to its content of saponins which inhibit the intestinal absorption of cholesterol and reduce serum cholesterol levels (Abo-Raya et al., 2013). This indicate that the effects of ginseng on serum lipid profiles may be mediated by the changes in the expression of PPAR $\alpha$ target genes thus inhibiting PPAR $\alpha$ function that may have therapeutic implications (Huang, 1999; Mahmoud et al., 2013). Improvements to lipid profile through ginseng administration are associated with activation and increased expression of peroxisome proliferator activated

Table (5): Effects Palm Pollen, Ginseng and their mixture between then on some blood parameters $(\mathrm{X} \pm \mathrm{SE})$ of the female Japanese Quail layers from 7 to 22 weeks of age.

\begin{tabular}{lcccccc}
\hline Items & $\begin{array}{c}\text { Total } \\
\text { Protein } \\
(\mathbf{g} / \mathbf{d l})\end{array}$ & $\begin{array}{c}\text { Albumen } \\
(\mathbf{g} / \mathbf{d l})\end{array}$ & $\begin{array}{c}\text { Tri- } \\
\text { Glycerides } \\
(\mathbf{m g} / \mathbf{d l})\end{array}$ & $\begin{array}{c}\text { Cholesterol } \\
(\mathbf{m g} / \mathbf{d l})\end{array}$ & $\begin{array}{c}\text { Glucose } \\
(\mathbf{m g} / \mathbf{d l})\end{array}$ & Estrogen \\
\hline Control & 4.62 & 2.51 & 286.69 & 219.92 & 141.00 & 79.00 \\
(Basal diet) & $\pm 0.16^{\mathrm{b}}$ & \pm 0.14 & $\pm 5.46^{\mathrm{a}}$ & \pm 6.81 & $\pm 6.56^{\mathrm{a}}$ & \pm 5.20 \\
Palm Pollen & 5.11 & 2.68 & 242.88 & 206.25 & 135.33 & 86.00 \\
$(\mathbf{P P})$ & $\pm 0.15^{\mathrm{b}}$ & \pm 0.25 & $\pm 6.62^{\mathrm{b}}$ & \pm 6.20 & $\pm 5.65^{\mathrm{a}}$ & \pm 4.36 \\
Ginseng & 5.17 & 2.80 & 239.00 & 207.81 & 130.20 & 94.67 \\
$\mathbf{( G )}$ & $\pm 0.21^{\mathrm{ab}}$ & \pm 0.13 & $\pm 4.16^{\mathrm{b}}$ & \pm 6.50 & $\pm 5.25^{\mathrm{ab}}$ & \pm 5.90 \\
$\mathbf{P P}+\mathbf{G}$ & 5.73 & 2.90 & 235.31 & 195.70 & 112.47 & 98.67 \\
\hline Sig. & $\pm 0.15^{\mathrm{a}}$ & \pm 0.19 & $\pm 4.69^{\mathrm{b}}$ & \pm 7.13 & $\pm 6.15^{\mathrm{b}}$ & \pm 6.12 \\
\hline
\end{tabular}

Means having different letters at the same column are significantly $(\mathrm{P} \leq 0.05)$ different.

$*=\mathrm{P}<0.05 ; * *=\mathrm{P}<0.01 ; \mathrm{NS}=$ Not significant. 
receptors, transcription factors regulating expression of proteins involved in lipid metabolism and adipocyte differentiation (Ni et al., 2010).

The high level of serum triglycerides in diabetic animals may be attributed to a decrease in the clearance and production of the major transporters of endogenously synthesized triglycerides (Abdel-Moneim, 1998). This decrease of clearance because of the decrease in adipose tissue lipoprotein lipase as demonstrated in human diabetics (Nikkila et al., 1977) and a decrease in hepatic triglycerides lipase as indicated in STZ-diabetic rats (Nakai et al., 1979). Also, the expansion of cholesterol pool in diabetes was explained by O'Meara et al. (1990) through the increased intestinal cholesterol synthesis, and the diminished synthesis of bile salts due to decreased hepatic phenol-2monooxygenase activity, the key enzyme responsible for the catabolism of cholesterol to bile acids. LDL-cholesterol elevation in the serum of diabetic rats could be attributed to a diminished number of peripheral LDL receptors or reduced LDL binding to its receptors (Betteridge, 1989 and Osman and Kandil, 1991).

\section{Histological studies:}

The histological results in male of quails treated with either PP or PG or their mixture showed an enhancement of the cellular activity and spermatogenesis in the testicular sections and the rich function of the epithelium and seminiferous tubules which showed by the increasing of the concentration of the spermatozoa in the lumen of the testes (Figure 2, 3 and 4) when compared to control group(Figure 1).

Panax ginseng was known to have protective and therapeutic effects against the testicular atrophy and other damages induced the most potent environmental pollutants toxic to reproductive organs (Kim et al., 1999). Ginseng-treated rats have demonstrated an increased rate of spermatogenesis via glial cell-derived neurotropic factor (GDNF) expression elevation in Sertoli cells (Yang et al., 2011), and activation of testicular cAMP-responsive element modulator (CREM), Park et al., (2007). Meng et al., (2000) and De Rooij (2001) found that the GDNF is a possible regulator of the survival and cell fate decision of undifferentiated spermatogonial cells, and CREM is essential for spermatid maturation (Behr and Weinbauer 2001). Hwang et al., (2010) indicate that ginseng improves the reduced feedback from the testes to the pituitary gland resulting in an increase in the amount of testosterone secreted from stimulates Leydig cells which may be degenerating and rejuvenation. 


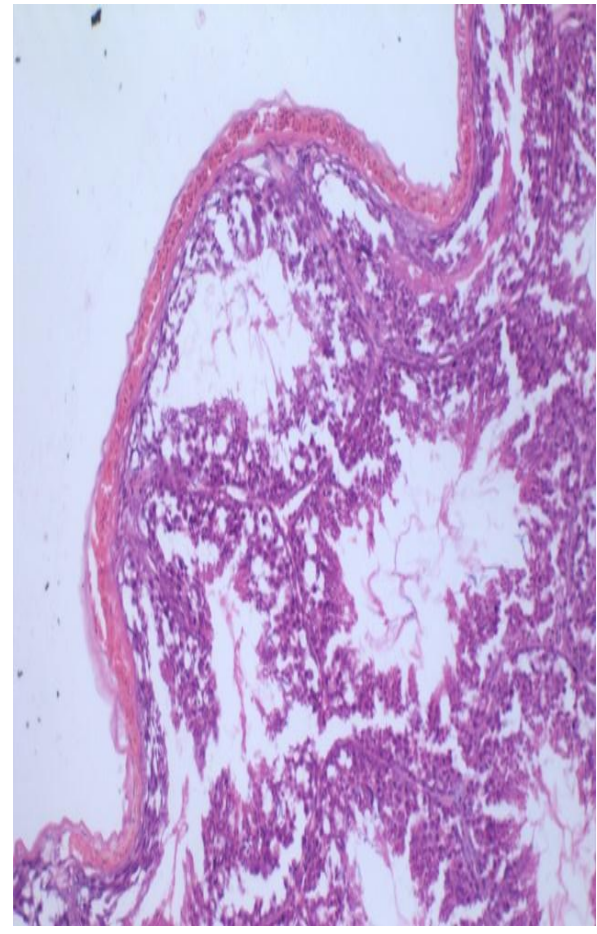

Fig. 1

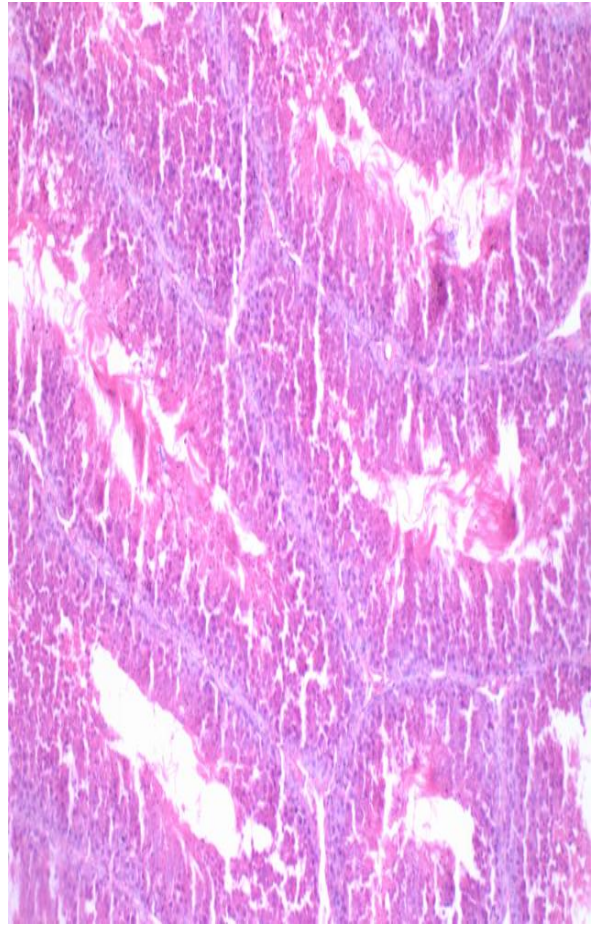

Fig. 2

Figure 1. Testis of male quails of control showed Irregular distribution, ,size and shape of some seminiferous tubules are observed. , While some tubules showed absent spermatozoa and thin basement membranes. Hemorrhage is seen in the lumens of most of tubule

Figure 2. Testis of male quails treated with $5 \mathrm{~g} \mathrm{PP} / \mathrm{kg}$. diet showed some of the seminiferous tubules appear irregularly arranged and assumed an irregular rounded to oval shapes. Irregular distribution, size and shape of some seminiferous tubules are observed. Most of the tubules showed regular spermatogenesis, while some tubules showed absent spermatozoa. 


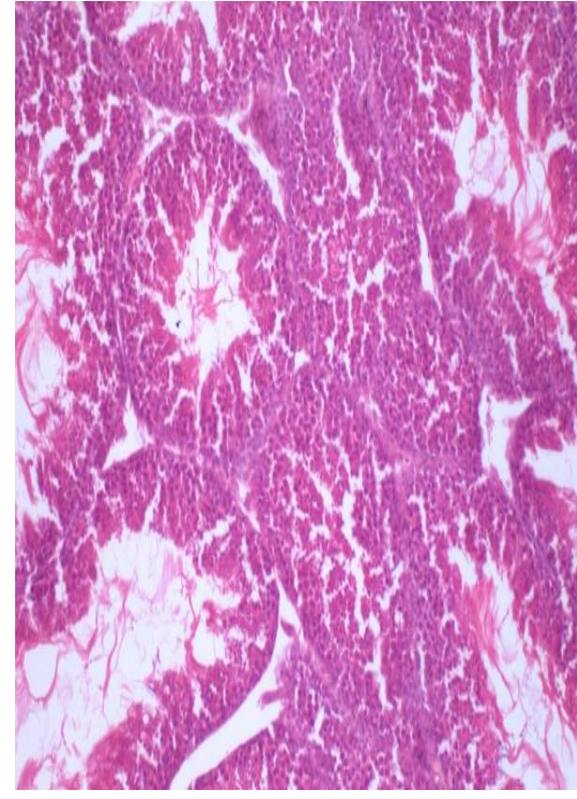

Fig. 3

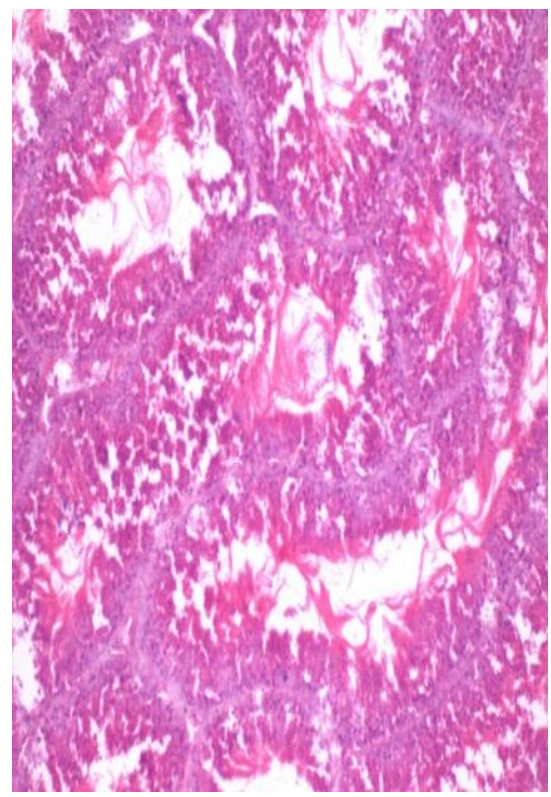

Fig. 4

Figure 3. Testis of male quails treated with $0.5 \mathrm{~g}$ PG / kg. diet showed uniform seminiferous tubules showing different stages of spermatogenesis with spermatozoa visible in lumen. But some seminiferous tubules appear irregularly arranged and assumed an irregular rounded to oval shapes.

Figure 4. Testis of male quails treated with $5 \mathrm{~g} \mathrm{PP}+0.5 \mathrm{~g} \mathrm{PG} / \mathrm{kg}$. diet showed uniform seminiferous tubules showing different stages of spermatogenesis with spermatozoa visible in lumen.

\section{Economical efficiency:}

Data in Table (6) revealed that the best economic efficiency (EE) value was shown by chicks fed diets supplemented with mixture between Palm pollen and Panax Ginseng than the other treatment groups. While, the lowest (EE) value was shown under control group. 
Table (6): Economic efficiency on the Japanese Quail layers from 7 to 22 weeks of age affected by Palm Pollen, Ginseng and their mixture between then .

\begin{tabular}{|l|c|c|c|c|}
\hline \multicolumn{1}{|c|}{ Items } & Control & PP & PG & PP + G \\
\hline Egg number & 70 & 76.00 & 77.00 & 81.00 \\
\hline Price/egg (LE) & 0.40 & 0.40 & 0.40 & 0.40 \\
\hline $\begin{array}{l}\text { Total revenue eggs } \\
\text { (LE) }\end{array}$ & 28.00 & 30.40 & 30.80 & 32.40 \\
\hline Total feed intake(kg) & 3.12 & 3.16 & 3.17 & 3.16 \\
\hline Price/Kg feed (LE) & 5.71 & 5.74 & 5.73 & 5.76 \\
\hline Total feed cost (LE) & 17.82 & 18.14 & 18.16 & 18.20 \\
\hline Fixed (LE) & 1.00 & 1.00 & 1.00 & 1.00 \\
\hline Total cost (LE) & 18.82 & 19.14 & 19.16 & 19.20 \\
\hline Net revenue (LE) & 9.18 & 11.26 & 11.64 & 12.80 \\
\hline $\begin{array}{l}\text { Economic efficiency } \\
\text { (EEf) }\end{array}$ & 48.82 & 58.84 & 60.72 & 68.74 \\
\hline
\end{tabular}

The price of $\mathrm{PP}=60 \mathrm{LE} / \mathrm{Kg}$. The price of $\mathrm{PG}=400 \mathrm{LE} / \mathrm{Kg}$. , Net revenue/quail $(\mathrm{LE})=$ Total revenue - Total cost/quail, EEF= Net revenue/quail(LE) / Total cost/quail (LE)

Conclusively, supplementing of $5 \mathrm{~g}$ Palm Pollen or $0.5 \mathrm{~g}$ Panax Ginseng/ kg. diet and their mixture in quails laying diet can be used safely to improve productive and reproductive performance of quails.

\section{REFERENCES}

Aarestrup F. M., Seyfarth A. M., Emborg H. D., Pedersen K., Hendriksen R. S., Bager, F., (2001). Effect of abolishment of the use of antimicrobial agents for growth promotion on occurrence of antimicrobial resistance in fecal enterococci from food animals in Denmark. Antimicrob Agents C.Hemother, 45(7):2054-2059.

Abo-Raya, O., Alfky, N. A. and AElgazar, F. (2013). Anti-Obesity and Antidiabetic Activities of Red Ginseng Plant Extract in Obese Diabetic Male Rats. Global Journal of Pharmacology, 7 (4): 390-397,

Abou El-Naga, M.K., (2014). Effect of bee pollen supplementation on productive and reproductive performance of Norfa chicken. Egypt. Poultry Science, 34: 119-132.

Adaay, M.H. and Mattar, A.G. (2012). Effect of aqueous and ethanolic extracts of Tribulus terrestris, Phoenix dactylifera and Nasturtium officinale mixture on some reproductive parameters in male mice. $J$. Baghdad Science, 9: 640-650. 
Agriculture Ministry Decree (1996). The standard properties for ingredients, feed additives and feed manufactured for animal and poultry. EL Wakaee EL-Masria, No. 192 (1997) P 95, Amirria Press Cairo, Egypt.

Arhaem S.H. (2004). Effects of use different level from water extract of date palm pollen on ovary function and some production characteristics. $\mathrm{Al}$ Furat Agriculture Science, 6(1):98-103.

Azazi, L.A.; M.A.S. Darwish; E.R. Abd El-Hameid; A.A. Habib and J.S., Razik (2011). Effect of dietary ginseng supplementation on productive and reproductive traits for Sinai layer strain. Journal Production Development, 16 (2): 287 - 305.

Bahmanpour S.T., Z. Talaei, M.R. Vojdani, A. Panjehshahin, S. Poostpasand, S. Zareei and Ghaeminia M.(2006). Effect of Phoenix dactylifera pollen on sperm parameters and reproductive system of adult male rats. Iran Journal Medical Science, 31:208-212.

Banchroft J.D., A. Stevens and D.R. Turner, (1996). Theory And Practice Of Histological Techniques. 4th Ed. Churchil Livingstone, New York, London, San Francisco, Tokyo.

Behr $\mathbf{R}$ and Weinbauer GF. (2001). cAMP response element modulator (CREM): an essential factor for spermatogenesis in primates? Int $J$ Androl., 24(3): 126-35.

Betteridge, D.J., 1989. Diabetes, lipoprotein metabolism and atherosclerosis. Br. Med. Bull., 45 (1), 285-311.

Bhatt N., 2015 Herbs and herbal supplements, a novel nutritional approach in animal nutrition.Iranian Journal of Applied Animal Science, 5:497-516.

Casewell M., Friis C., Marco E., Mc Mullin P., Phillips I., (2003). The European ban on growth-promoting antibiotics and emerging consequences for human and animal health. Journal Antimicrob Chemother, 52(2):159-161.

De Rooij DG. (2001). Proliferation and differentiation of spermatogonial stem cells. Reproduction; 121: 347-54.

Duncan, D. D.(1955). Multiple range and Multiple F-Test .Biometrics .11:1 -42.

Hassan WA., AM. El-kashlan and NA. Ehssan (2012). Egyptian date palm pollen ameliorates testicular dysfunction induced by cadmium chloride in adult male rats. Journal American Science;8 (4):659-669. 
Hassan, A.M. and Abdel-Wahhab, M.A. (2006). Antioxidant effect of parsley and panax ginseng extract standardized with ginsenosides $\mathrm{Rg} 3$ against alteration induced in reproductive functions in male mice. Egyptian Journal of Hospital Medicine, 22:60-72.

Hwang SY, Kim WJ, Wee JJ, Choi JS, and SK. Kim (2004). Panax ginseng improves survival and sperm quality in guinea pigs exposed to 2,3,7,8-tetrachlorodibenzo- p-dioxin, BJU Int.; 94: 663-668

Hwang, S.Y., Hyun S., Jae-J. Wee, J.-B. Yang, J. S., Kyung, Y. S., Kwak, S. W. Kim, and Kwan, K.(2010). Panax ginseng Improves Senile Testicular Function in Rats. Journal Ginseng Res., 34: (4): 327-335.

Huang, K.C. (1999). The Pharmacology of Chinese Herbs. CRC Press, Boca Raton, FL.

Iftikhar, S., A. Bashir, M.S. Anwar, S.M. Mastoi and M. Shahzad, 2011. Effect of Date Palm Pollen (DPP) on serum testosterone levels in prepubertal albino rats. Pakistan Journal Medicine Health Science, 5: 639-644.

Jang HD, Kim HJ, Cho JH, Chen YJ, Yoo JS, Min BJ, Park JC, Kim IH. (2007) .Effect of dietary supplementation of fermented wildginseng culture byproducts on egg productivity, egg quality, blood characteristics and ginsenoside concentration of yolk in laying hen. Korean Journal Poultry Sciences; 34:271-278.

Jang J. P., (2011). Comparison of effect of cyminum and probiotic on Japanese quail males. Journal Agriculture Science, 8.(3) : 86-91.

Kang H. K., Park S.-B., and C. H. Kim(2016). Effect of Dietary Supplementation of Red Ginseng By-product on Laying Performance, Blood Biochemistry, Serum Immunoglobulin and Microbial Population in Laying Hens. Journal Animal Science, Vol., 29(10): 1464-1469.

Kawak, Y.S.; Kyung, J.S.; Kim, J.S.; Cho, J.Y. and Rhee, M.H. (2010). Antihyperlipidemic effects of red ginseng acidic polysaccharides from Korean red ginseng. Biol. Pharm. Bull., 33(3): 468-472.

Kiefer, D. and Pantuso, T. (2003). Panax ginseng. Am Fam. Physician, 68:1539- 1542.

Kim ,W.; Hwang, S.; Lee, H.; Song, H. and Kim, S. (1999). Panax ginseng protects the testis against 2,3,7, 8-tetrachlorodibenzo-p-dioxin induced testicular damage in guinea pigs. BJU Int.; 83:842-849. 
Kim Y. J., Leeb G. D. and I. H.Choi (2015). Effects of dietary red ginseng marc on egg production, egg quality and blood characteristics of laying hens. J. of Applied Animal Research, Vol. 43(2): 242-246.

Kim, D. H.; Moon, Y. S.; Lee, T. H.; Jung, J. S.; Suth, H. W. and Song, D. K. (2003). The inhibitory effect of ginseng saponins on the stressinduced plasma interleukin-6 level in mice. Neutrosci. Lett., 1: 13-16.

Kim, S. H. and Park, K. S. (2003): Effects of Panax ginseng extract on lipid metabolism in humans. Pharmacol. Res., 48: 511-513.

Kumar, M.; Sharma, M.K.; Saxena, P.S. and Kumar, A. (2003). Radioprotective effect of Panax ginseng on the phosphatases and lipid peroxidation level in testes of Swiss albino mice. Biological and Pharmaceutical Bulletin., 26(3):308-312.

Malviya S., Jain S. Gupta .B.V. and S. Vyas (2011) . Recent studies on aphrodisiac herbs for the management of male sexual dysfunction - a review. Acta Poloniae Pharmaceutica -Drug Research, Vol. 68(1 ): 38,201

Meng X, Lindahl M, Hyvönen ME, Parvinen M, de Rooij DG, Hess MW, Raatikainen-Ahokas A, Sainio K, Rauvala H, Lakso M, (2000). Regulation of cell fate decision of undifferentiated spermatogonia by GDNF. Science, 287: 1489-1493.

Mohammed, S. A.; Yaqub, A. G.; Sanda, K. A.; Nicholas, A. O.; Arastus, W.; Muhammad, M. and Abdullahi, S. (2013). Review on diabetes, synthetic drugs and glycemic effects of medicinal plants. J. Med. Plants Res., Vol. 7(36): 2628-2637.

Muwalla, M. M. and N. M. Abuirmeileh. (1990). Suppression of avian hepatic cholesterogenesis by dietary ginseng. J. Nutr. Biochem., 1:518-521.

Nakai, T., Yamada, S., Tamai, T., Kobayashi, T., Hayashi, T., Takida, R., 1979. The effect of streptozotocin diabetes on hepatic triglyceride lipase activity in the rat. Metabolism, 28 (1), 30-40

Ni, H.; Yu, N. and Yang, X. (2010). The Study of Ginsenoside on PPAR gamma Expression of Mononuclear Macrophage in Type 2 Diabetes. Mol.Biol. Rep., 37(6):2975-2979.

Nikkila, E.A., Huttunen, J.K. and Ehnholm, C., (1977). Post heparinplasma lipoprotein lipase and hepatic lipase in diabetes mellitus: relationship to plasma triglycerids metabolism. Diabetes, 26, 11-21.

Nocerino E., Amato M., A.A. Izzo (2000). The aphrodisiac and adaptogenic properties of ginseng. Fitoterapia ,71: 1 . 
NRC. 1994. Nutrient Requirements of Domestic Animals. Nutrient Requirements of Poultry (9th ed). National Academic Press, Washington, D.C., USA.

O'Meara, N.M., Devery, R.M., Owens, D., Collins, P.B., Johnson, A.H., Tomkin, G.H., 1990. Cholesterol metabolism in alloxan induced diabetic rabbits. Diabetes, 39, 626-633.

Omar, M.M., A.A. Shanawany and M.K. Mohsen, (1989). The effect of palm pollen grains and date extracts on the spermatogenic activity of male guinea pigs. Arch. Biochem. Biophys., 4: 433-435.

Ommati, M. M.; Zamiri, M. J.; Akhlaghi, A.; Atashi, H.; Jafarzadeh, M. R.; Rezvani, M. R. and Saemi, F. 2013. Seminal characteristics, sperm fatty acids, and blood biochemical attributes in breeder roosters orally administered with sage (Salvia officinalis) extract. Animal Production Science, 53:548-554.

Osman, H.M., Kandil, M.T., 1991. Effect of insulin and/or oral hypoglycemic drugs on the serum glucose level and lipid profile in streptozotocin induced diabetes. El-Minia Med. Bull., 2 (2): 174- 192.

ÖZCAN M. A.(2016). The Effects Of Adding Of Panax Ginseng Root Extract On Egg Production And Some Blood Parameters In Japanese Quail Diets. Journal Science Technology, Vol.6(2):68-74.

Pan S. Y., Litscher G., Gao S. H., Zhou S. F., Yu Z. L., Chen H. Q., Ko K. M., (2014). Historical perspective of traditional indigenous medical practices: the current renaissance and conservation of herbal resources. Evid Based Complement Alternat Med:525340. doi: 10.1155/525340.

Park WS, Shin DY, Kim R, Yang WM, Chang MS and Park SK. (2007). Korean ginseng induces spermatogenesis in rats through the activation of cAMP-responsive element modulator (CREM). Fertil Steril., 88(4): $1000-2$.

Qureshi A.A., Abuirmeileh N., Din Z.Z., Elson C.E. and W.C. Burger (1983). Inhibition of cholesterol and fatty acid biosynthesis in liver enzymes and chicken hepatocytes by polar fractions of garlic. Lipids, 18: 343-348.

Sabah A. and A. Linjawi 2015). Evaluation of the Protective Effect of Panax Ginseng Nanoparticles against Nicotineinduced Reproductive Disorders in Male Rats. Int. J. Pharm. Sci. Rev. Res., 32(1), May - June 2015; Article No. 06, Pages: 38-45. 
SAS Institute. (2004). SAS User's Guide: Statistics. Edition 9.1.SAS Institute Inc., Cary, NC.

Shanoon A. Q., Jassim M. S., Mohamed A. H., Latef M. S., and A. M. Abad AL-Raheem(2015). The Effect of Using Different Levels from Date Palm Pollen in Diet on Productive Performance and Some Eggs Quality Measurements for Layer Hens Lohman. Animal and Veter. Science, 3(6-1): 1-4

Shin, S.K.; Kwon, J.H.; Jeong, Y.J.; Jeon, S.M.; Choi, J.Y. and Choi, M.S. (2011). Supplementation of cheonggukjang and Korean red ginseng Cheonggukjang combination can improve plasma lipid profile and fasting blood glucose concentration in subjects with impaired fasting glucose. J. Food Med., 14: 108-113.

Tahani Y. Omar* and Y. K. A. Abdalhafid(2016). Effect of Panax Ginseng root powder on fertility and antioxidant enzymes in male rabbits. Eur. J. of Ph. and Mid. Rec. :3 (5), 76-83.

Walzem, R. L., R. J. Hansen, D. L. Williams, and R. L. Hamilton. 1999. Estrogen induction of VLDLy assembly in egg-laying hens. Journal Nutrition, 129:467S-472S.

Watson P. F. ( 1975 ) . Use of a Gimsa stain to detect changes in acrosomes of frozen ram spermatozoa. Veterinary Record, $97: 12-15$.

Wu, J. and J. J. Zhong (1999). Production of ginseng and its bioactive components in plant cell culture: Current technological and applied aspects. Journal Biotechnology, 68 (2): 89-99.

Yan, L.; Q. W. Meng; X. Ao; J.P. Wang; H. D. Jang and I. H. Kim (2011). Evaluation of dietary wild-ginseng adventitious root meal on egg production, egg quality, hematological profiles and egg yolk fatty acid composition in laying hens. Livestock Science, 140 (13):201-205.

Yang WM, Park SY, Kim HM, Park EH, Park SK and Chang MS. (2011). Effects of Panax ginseng on glial cellderived neurotrophic factor (GDNF) expression and spermatogenesis in rats. Phytother Res., 25(2): 308-11.

Zhiyue W., Ling Z. and Z. Xiuli (2002).Effect of Adding Pollen in Diets on the Sperm Quality and Endocrine Capacity of Breeder Cocks under Heat Stress. 


\section{تأثير اضافة طلع النخيل والجنسنج على الصفات الانتاجية والتناسلية ويعض القياسات الفسيولوجية للسمان الياباني البياض.

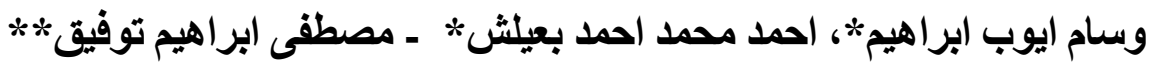

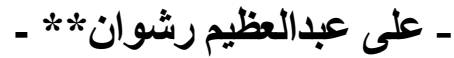

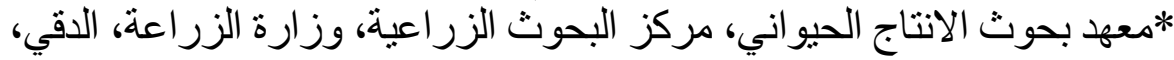

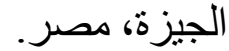

**قم الانتاج الحيو اني و الدو اجن، كلية التنمية والتكنولوجيا، جامعة الزقازيق، مصر.

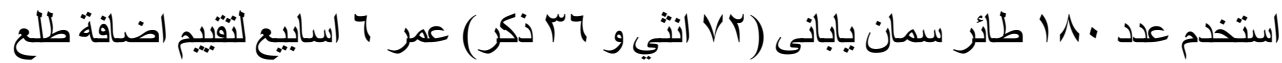

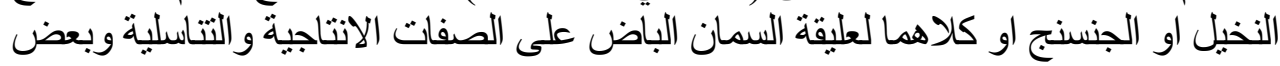

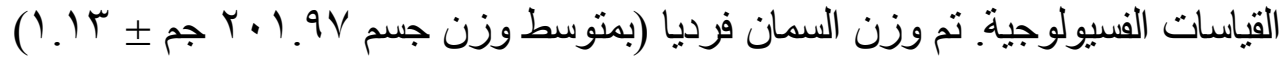

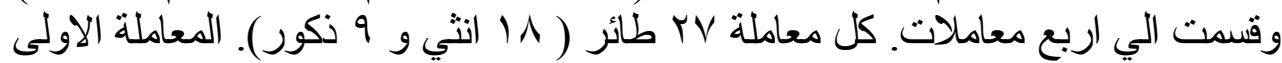

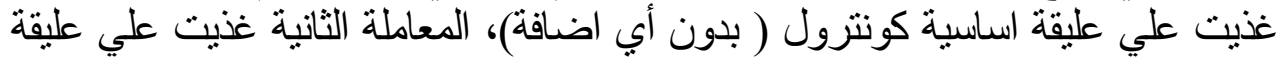

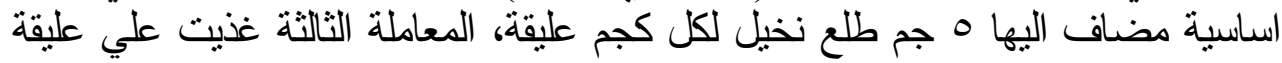
اساسية مضاف اليها ه. • جم جنسنج لكل كجم عليقة، المعاملة الرابعة غذيت عليت علي عليقة

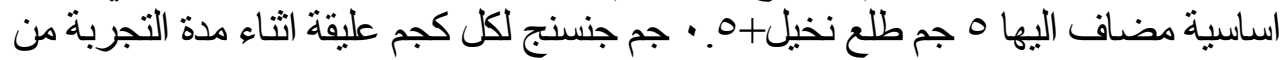

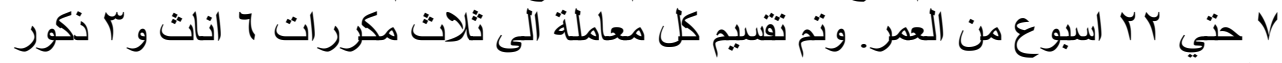

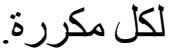

اظهرت النتائج ان تغنية السمان بإضافة طلع النخيل او الجنسنج او كلاهما معا زاد

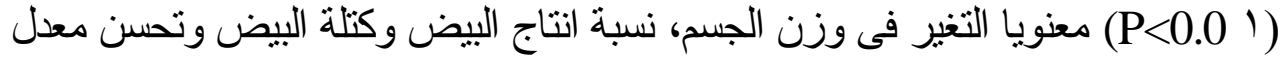

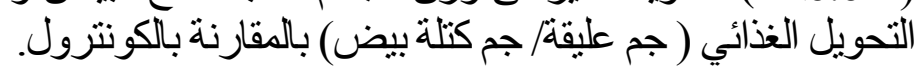

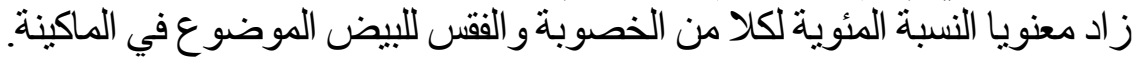

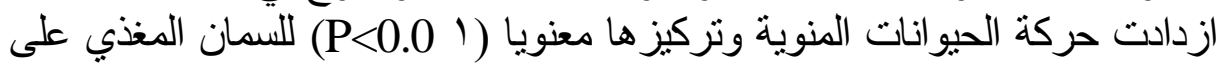

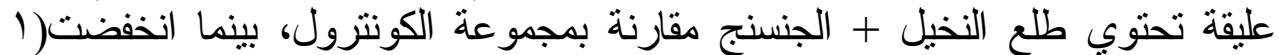

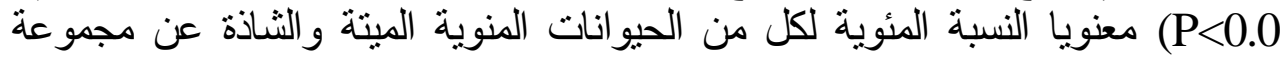

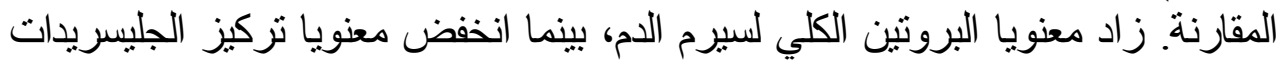

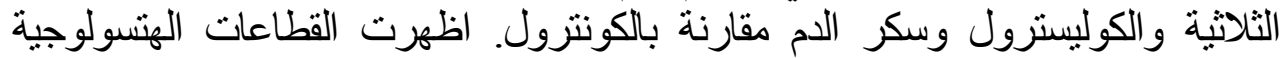

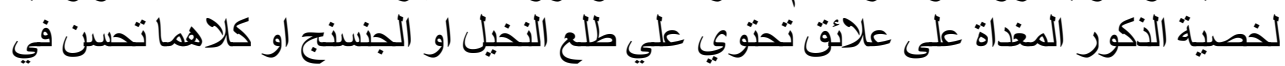
النشاط الخلوي وتكوين الاسبرماته الخئ.

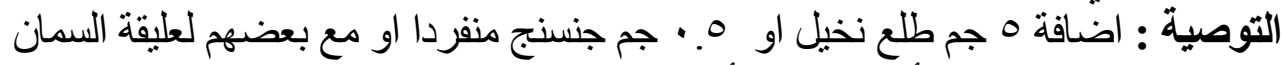
اليياض بمكن ان تستخدم بأمان لزيادة الأداء الإنتاجي و التناسلي للسمان. 